\title{
The utility of magnetic resonance imaging in a trial to assess the effect of renal denervation in heart failure with preserved ejection fraction
}

\author{
Ricardo Wage ${ }^{1 *}$, Hitesh Patel', Gillian C Smith', Jennifer Keegan'1, Peter Gatehouse', Vassilis Vassiliou', \\ Ee Ling Heng', Carl Hayward', Stuart D Rosen², Alexander Lyon', Raad Mohiaddin', Sanjay K Prasad', \\ Dudley J Pennell ${ }^{1}$, Carlo Di Mario ${ }^{1}$
}

From 18th Annual SCMR Scientific Sessions

Nice, France. 4-7 February 2015

\section{Background}

Heart failure with preserved ejection fraction (HF-PEF) is common and has a poor prognosis with a 3 year mortality rate of $23 \%$. There are currently no effective therapies for this condition. HF-PEF is characterized by symptoms of heart failure, normal or a mildly impaired ejection fraction and evidence of adverse cardiac and vascular remodelling. A feature of all heart failure is a heightened sympathetic nervous system (SNS), which can now be abrogated using renal denervation (RD).

\section{Methods}

We are conducting a study of patients with HF-PEF who will be randomised (2:1) to receive RD or open control. As a phase II mechanistic study we are primarily investigating the effect of RD on patient symptoms (questionnaire), cardio-pulmonary exercise function, B-type natriuretic peptide levels, left ventricular filling pressures, left ventricular mass and left atrial volume. We are also assessing macrovascular function using aorta imaging to calculate aorta distensibility, pulse wave velocity and aortic flow. Finally,

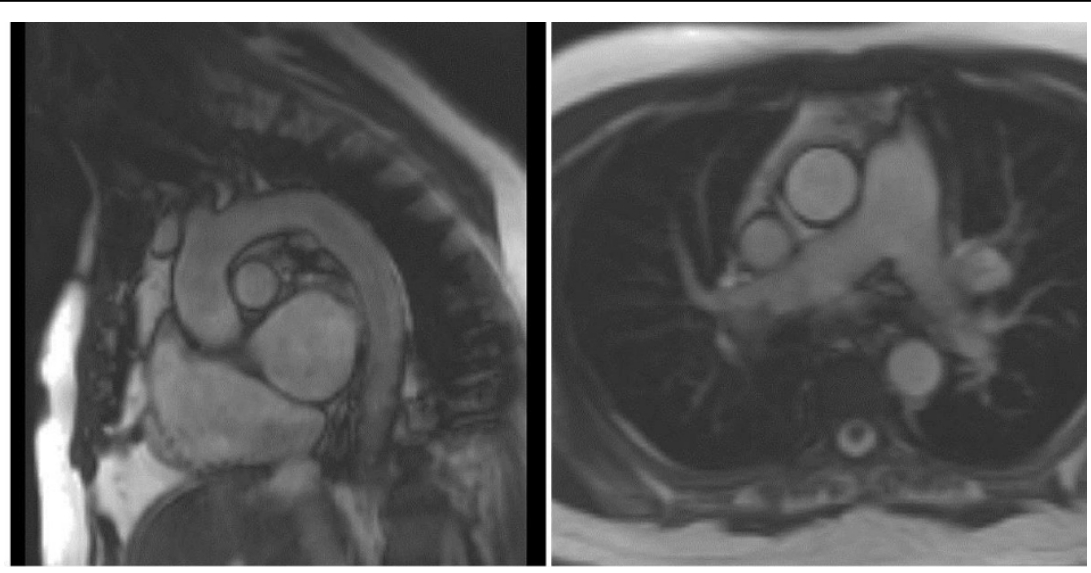

Figure 1 Left image: Trufisp-GRE cine of the aorta and arch.Right image: Through plane of the ascending and descending aorta at pulmonary artery level. This image will be used to plan the aorta distensibility and pulse wave velocity sequences.

${ }^{1}$ Royal Brompton Hospital, London, UK

Full list of author information is available at the end of the article

(c) 2015 Wage et al; licensee BioMed Central Ltd. This is an Open Access article distributed under the terms of the Creative Commons 


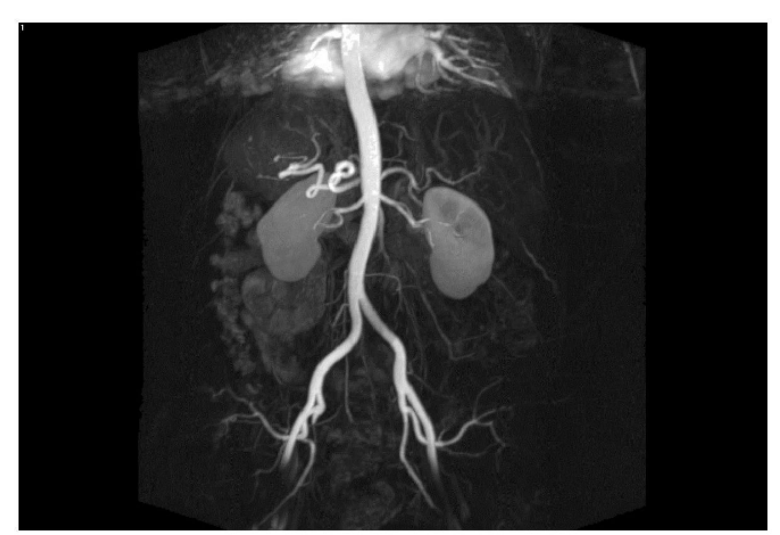

Figure 2 Magnetic resonance angiography of the renal arteries.

we will investigate the effect of RD on renal artery blood flow. Cardiac, aorta and renal magnetic resonance image (MRI) sequences will be used to provide this data. Tests will be performed at baseline, three months and 12 months.

\section{Results}

The study is on-going. Currently 25 patients have been randomized. Quantitative MRI will be performed blinded. Examples of baseline data will be presented for illustrative purposes.

\section{Conclusions}

The effects of RD on the heart, vasculature and the kidneys have not been fully elucidated. Using MRI, we aim to clarify some of the mechanisms of action of RD in a population of patients with HF-PEF.

\section{Funding}

NIHR Cardiovascular Biomedical Research Unit, Royal Brompton Hospital, UK.

\section{Authors' details}

${ }^{1}$ Royal Brompton Hospital, London, UK. Ealing Hospital, London, UK.

Published: 3 February 2015

doi:10.1186/1532-429X-17-S1-T7

Cite this article as: Wage et al:: The utility of magnetic resonance imaging in a trial to assess the effect of renal denervation in heart failure with preserved ejection fraction. Journal of Cardiovascular Magnetic Resonance 2015 17(Suppl 1):T7.
Submit your next manuscript to BioMed Central and take full advantage of:

- Convenient online submission

- Thorough peer review

- No space constraints or color figure charges

- Immediate publication on acceptance

- Inclusion in PubMed, CAS, Scopus and Google Scholar

- Research which is freely available for redistribution 